\title{
Determination of the physiological and biochemical effects of humic acid application in strawberry plant grown under salt stress
}

\section{Tuz stresinde yetiştirilen çilek bitkisinde hümik asit uygulamasının fizyolojik ve biyokimyasal etkisinin belirlenmesi}

\author{
Sema KARAKAS ${ }^{1 *}$ iD, Murat DIKILITAS² iD \\ ${ }^{1}$ Department of Soil Science and Plant Nutrition, Faculty of Agriculture, Harran University, Sanliurfa 63300, Turkey \\ ${ }^{2}$ Department of Plant Protection, Faculty of Agriculture, Harran University, Sanliurfa 63300, Turkey \\ ${ }^{1}$ https://orcid.org/0000-0003-1617-9407; ${ }^{2}$ https://orcid.org/0000-0002-7399-4750
}

\section{To cite this article:}

Karakas, S. \& Dikilitas, M. (2021). Determination of the physiological and biochemical effects of humic acid application in strawberry plant grown under salt stress. Harran Tarım ve Gıda Bilimleri Dergisi, 25(3): 326-335.

DOI: 10.29050/harranziraat.905113

*Address for Correspondence: Sema KARAKAS

e-mail:

skarakas@harran.edu.tr

Received Date:

29.03.2021

Accepted Date:

21.06.2021

(C) Copyright 2018 by Harran University Faculty of Agriculture. Available on-line at www.dergipark.gov.tr/harranziraat

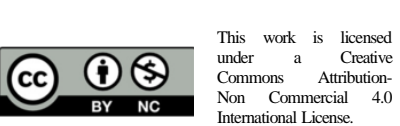

\section{ABSTRACT}

The reduction of salt toxicity in the soil environment significantly contributes to the growth and development of plants. In this study, tolerance and development status of strawberry plant were investigated through irrigation solution including $50 \mathrm{mmol} \mathrm{L^{-1 }} \mathrm{NaCl}$ salinity and the application of $50 \mathrm{mg} \mathrm{L}^{-1}$ humic acid (HA). The physiological and biochemical parameters in vegetative and fruit stages and the mineral contents of strawberry plants were assessed if application of HA contributed to salt tolerance mechanisms of strawberry plants. HA improved physiological parameters such as crown and root fresh weight, crown and root dry weight, stomatal conductance as well as improving biochemical parameters and reducing stress metabolites such as (total chlorophyll contents, proline, malondialdehyde, catalase, and peroxidase enzyme activities). HA application $\left(50 \mathrm{mg} \mathrm{L}^{-1}\right)$ under salt stress $\left(50 \mathrm{mmol} \mathrm{L}^{-1}\right)$ also improved the quality parameters such as vitamin $C$ and lycopene contents. We suggest that HA application is beneficial via increasing the tolerance mechanisms of salt-sensitive strawberry plants.

Key Words: $\mathrm{NaCl}$ stress, humic acid, strawberry, abiotic stress

\section{öz}

Topraktan tuz toksisitesinin azaltılması, bitkilerin büyüme ve gelişimine önemli katkılar sunmaktadır. Bu çalışmada $50 \mathrm{mmol} \mathrm{L}^{-1} \mathrm{NaCl}$ içeren sulama suyu ile sulanan çilek bitkisinin 50 $\mathrm{mg} \mathrm{L}^{-1}$ hümik Asit (HA) uygulaması ile tuz stresine karşı toleransı ve gelişim durumu araştırılmıştır. Çilek bitkilerinin tuz toleransına HA uygulamasının katkıda bulunup bulunmadığı, vejetatif ve meyve aşamalarında fizyolojik ve biyokimyasal parametreler ve çilek bitkilerinin mineral içerikleri değerlendirilmiştir. HA, taç ve kök taze ağırlığı, taç ve kök kuru ağırlı̆̆ı, stomatal iletkenlik gibi fizyolojik parametri ve bunun yanı sıra artan biyokimyasal parametreler ve azalan stres metabolitleri ile (toplam klorofil, prolin, MDA, katalaz ve peroksidaz) bitki gelişimini sağlamıştır. Tuz stresi altında $\left(50 \mathrm{mmol} \mathrm{L}^{-1}\right) \mathrm{HA}$ uygulamasının 50 $\mathrm{mg} \mathrm{L}^{-1}$ vitamin $\mathrm{C}$ likopen gibi kalite parametrelerini artırdığı belirlenmiştir. HA uygulaması tuza hasas olan çilek bitkisinin tolerans mekanizmasını artırarak fayda sağlamıştır.

Anahtar Kelimeler: $\mathrm{NaCl}$ stres, hümik asit, çilek, abiotik stres

\section{Introduction}

Salt stress is a very important abiotic stress affecting plant growth, crop production and quality. Increased salinity in the root media impacts plants during their vegetative growth periods via decreasing plant growth and yield (Wani and Gosal, 2011). Some crop plants have 
limited capacity to tackle with salt stress. Application of proper fertilization and irrigation or genetic improvement may help to increase the salt tolerance mechanisms in salt-sensitive crop plants. However, additional help is mostly needed to grow them under stressed conditions.

Strawberry is a small fruit crop that is highly valuable all over the world. It belongs to the Rosaceae family with 23 species in the genus Fragaria. (Folta and Davis 2006; Shulaev et al. 2008). Strawberry is an important commercial fruit crop with the increasing production areas and consumption around the world. However, it is considered sensitive to $\mathrm{NaCl}$ due to toxic $\mathrm{Na}^{+}$or $\mathrm{Cl}^{-}$ions. $\mathrm{NaCl}$ stress not only reduces the crop yield but also deteriorates the quality parameters in strawberry fruits (Jamalian et al., 2013; Garriga et al., 2015).

We could reduce the negative effects of salinity through the application of chemicals. Humic acid (HA) is one of the benefical chemicals to have a key role in the promotion of plant growth as biostimulation. HA can enhance stress tolerance of plants. It has been widely used in water stress, salinity stress and even in biotic stress agent conditions (Aydin et al., 2012). It regulates plant primary and secondary metabolism in stress conditions and increases resistance against abiotic and biotic stresses (Canellas and Olivares, 2014; Canellas et al., 2015). HA could help crop plants enhance a variety of biochemical processes by growing the activity of enzymatic antioxidants including CAT, POD, and SOD, cell membrane stability, regulating water absorption and increasing the uptake of mineral elements and synthesis of proteins and hormones. Humic acid also regulates hormonal homeostasis and positively affects plant growth (Ali et al., 2019). HA also contribute to soil fertility via regulating chemical reactions in the vicinity of plant roots (Trevisan et al., 2009; Geçer, 2020).

In this study, physiological and biochemical responses of Rubygem strawberry cultivar against $\mathrm{NaCl}$ salinity were assessed and the effect of $\mathrm{HA}$ in terms of growth improvement, mineral contents availability and fruit quality parameters.

\section{Materials and methods}

\section{Experimental design and plants growth}

This research was conducted in a semicontrolled greenhouse. Fresh strawberry (Rubygem variety) plants were grown in 8-L pots containing peat under natural light conditions. Day and night mean temperatures were $30 \pm 2 / 24 \pm 2{ }^{\circ} \mathrm{C}$. A trial was a randomized design with three different factors. The first factor was salinity stress which included two treatments containing 0 (control) and $50 \mathrm{mmol} \mathrm{L}^{-1} \mathrm{NaCl}$ stress. The second factor was HA treatments used on plant leaf at $50 \mathrm{mg} \mathrm{L}^{-1}$ and the third factor was the application of both salt and humic acid ( $\mathrm{NaCl}+\mathrm{HA})$ treatment. Treatments in each group were replicated five times.

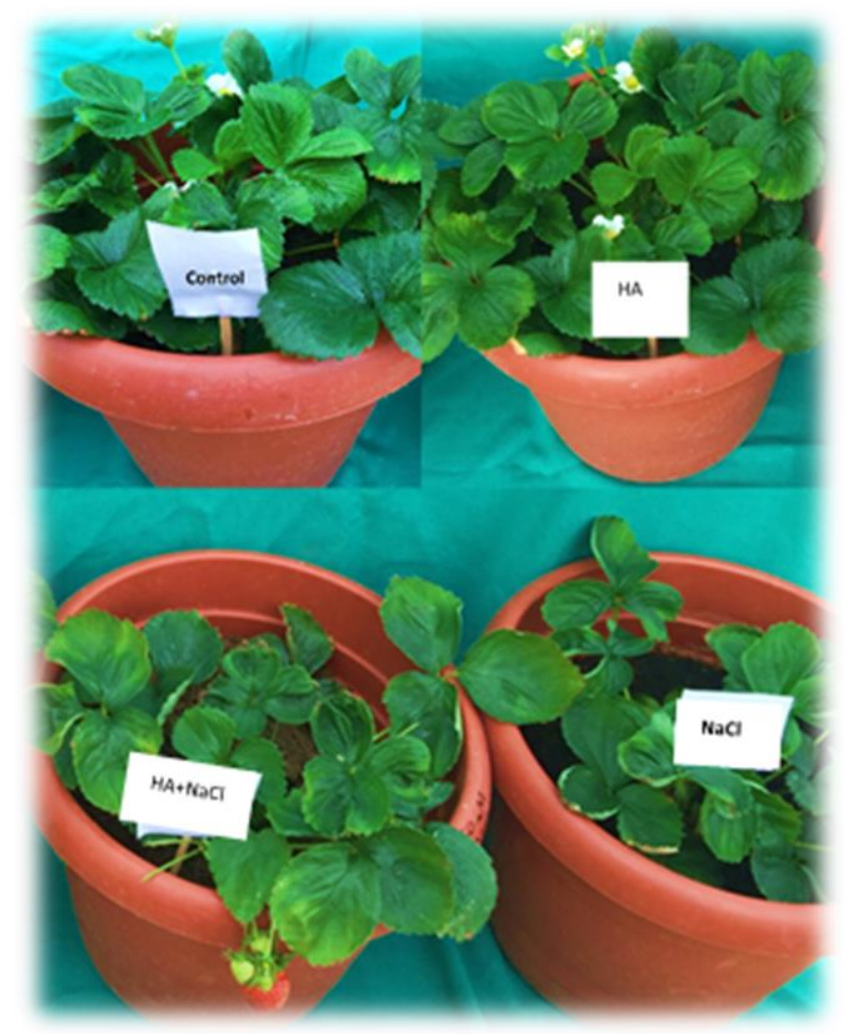

Figure 1. Strawberry plants were grown with or without HA and $\mathrm{NaCl}$ applications during the trial

Commercially available strawberry seedlings were transferred to the pots and kept until they formed 4 to 5 fully-developed leaves ( 5 weeks). Salinity and HA treatments were made once a week. The experimental treatments were made for a period of ten weeks. The whole trial period from the beginning of obtaining strawberry 
seedlings till the end of harvest took four months (Figure 1).

\section{Plant and fruit analyzes}

Plant crown and root fresh weight (FW) were analyzed immediately after the harvest. Plant crown and root dry weight (DW) were determined after drying them at $70^{\circ} \mathrm{C}$ to reach a constant weight.

Total soluble solids (TSS) were assessed from the fruit juice with a hand refractometer. The results are expressed in percent (\%) (Catania et al., 2020).

Stomatal conductivity was determined on the youngest fully expanded leaves on upper branches of the plants with a leaf promoter (SC-1) at midday. Measurements were conducted by clamping the leaves in the leaf chamber. The actual vapour flux from the leaf through the stomata is expressed as $\mathrm{mmol} \mathrm{m} \mathrm{m}^{-2} \mathrm{~s}^{-1}$ (Karlidag et al., 2011).

Strawberry fruits were harvested when $90 \%$ of the fruit surface had reached a fully red colour. At the end of the experiment, total fruit weights were determined, and the average fruit yield was calculated and expressed as g plant ${ }^{-1}$.

Lycopene content of strawberry fruits was assessed with the method of Barrett and Anthon (2001) with minor modifications (Karakas, 2013). Strawberry fruit (one gram) was homogenized in $10 \mathrm{~mL}$ of ethanol: hexane (4:3) mixture. The homogenate centrifuging the mixture at $10,000 \mathrm{~g}$ for $10 \mathrm{~min}$, then $0.1 \mathrm{~mL}$ of the supernatant was mixed with $7 \mathrm{~mL}$ of ethanol:hexane (4:3) mixture and vortexed. After $1 \mathrm{~h}$ of room temperature incubation, $1 \mathrm{~mL}$ of $\mathrm{H} 2 \mathrm{O}$ was applied to the tubes and vortexed. A sample of the organic (hexane) phase was measured at $503 \mathrm{~nm}$ compared with hexane in a UV microplate spectrophotometer (Epoch, SN: 1611187, USA). The results are expressed as $\mathrm{mg} \mathrm{kg}^{-1} \mathrm{FW}$.

The vitamin $C$ content of fruits was assessed following the method of Oz (2002) with small modifications (Karakas, 2013). Strawberry fruits (five grams) were extracted in $25 \mathrm{~mL}$ of oxalic acid. The mixture was centrifuged at $10,000 \mathrm{~g}$.
Then, $1 \mathrm{~mL}$ of the mixture was added to $7 \mathrm{~mL}$ of $1 \%$ oxalic acid and $8 \mathrm{~mL}$ of dye reagent. The ingredients of dye reagent and the experimental protocol was explained in our previous work (Karakas et al., 2016).

\section{Biochemical analyzes}

Total chlorophyll contents (Chl- $a+\mathrm{Chl}-b)$ of strawberry plants were assessed following the method of Arnon (1949) with minor modifications (Karakas, 2013). Leaf samples (0.5 g) were extracted with $10 \mathrm{~mL}$ acetone: water $(80 / 20, \mathrm{v} / \mathrm{v})$ mixture and filtered through Whatman No.2 filter paper and the supernatants were measured at UV microplate spectrophotometer (Epoch, SN: 1611187, USA) at $663 \mathrm{~nm}$ and $645 \mathrm{~nm}$ for Chl- $a$ and $\mathrm{Chl}-b$, respectively. The blank was $80 \%$ acetone. The results are calculated as $\mathrm{mg} \mathrm{L}^{-1}$ and expressed as $\mathrm{mg} \mathrm{g}^{-1} \mathrm{FW}$.

The proline contents of strawberry leaves were assessed according to the method of Bates et al. (1973) with minor modifications. The detailed protocol was previously described (Karakas et al., 2013). The results are expressed as $\mu \mathrm{mol} \mathrm{g}^{-1} \mathrm{FW}$.

Malondialdehyde (MDA) content was assessed following the process of Sairam and Saxena (2000) with minor modifications. The detailed protocol was previously described (Karakas et al., 2013). The results are expressed as $\mathrm{nmol} \mathrm{g}^{-1} \mathrm{FW}$.

Catalase (CAT, EC. 1.11.1.6) and POX (POX, EC.1.11.1.7) enzyme activities were assessed according to the methods of Milosevic and Slusarenko (1996) and by Cvikrova et al (1994), respectively with minor modifications (Karakas et al., 2013). The detailed protocols for both experiments were made in the previous study (Karakas et al., 2013).

Leaf mineral $\left(\mathrm{K}^{+}, \mathrm{Na}^{+}, \mathrm{Ca}^{+2}, \mathrm{Mg}^{+2}, \mathrm{Cl}^{-1}\right)$ contents were assessed following the procedure of Chapman and Pratt (1961) with minor modifications (Karakas, 2013). Dry plant samples (0.5) $\mathrm{g}$ were ground in porcelain crucibles. The porcelain crucibles were placed into a muffle furnace, and the temperature was gradually increased up to $500^{\circ} \mathrm{C}$. The cooled ash was then dissolved in $5 \mathrm{~mL} 2 \mathrm{~N}$ hydrochloric acid. After 30 
minutes, the volume was made up to $50 \mathrm{~mL}$ with distilled water, and the supernatant was filtered through Whatman No. 42 filter paper. Then resulting supernatant containing $\mathrm{Na}^{+}, \mathrm{K}^{+}, \mathrm{Ca}^{+2}$, and $\mathrm{Mg}^{+2}$ ions were assessed by Inductively Coupled Plasma (ICP, Perkin Elmer). The concentration of $\mathrm{Cl}^{-}$in the leaves was read using ion chromatography.

\section{Statistical analyzes}

Duncan's Multiple Range Test (DMRT) was used to evaluate the data at the $P \leq 0.05$ level using the ANOVA test in SPSS version 22. Data are expressed as a mean value \pm the standard error.

\section{Results and Discussion}

We determined that crown FW and DW, root FW and DW, stomatal conductance, total soluble solids, fruit average weight and total yield, lycopene, vitamin C, chlorophyll ( $\mathrm{Chl}-a$ and $\mathrm{Chl}-b$ ), leaf ions contents $\left(\mathrm{K}^{+}\right.$and $\left.\mathrm{Ca}^{2+}\right)$ of strawberry plants decreased in $\mathrm{NaCl}$-treated plants. Leaf proline contents, MDA, CAT and POX enzyme activities, leaf mineral contents $\left(\mathrm{Na}^{+}\right.$and $\left.\mathrm{Cl}^{-}\right)$of strawberry plants increased with $\mathrm{NaCl}$ treatment. Statistical analysis showed that HA application had significant effects on the crown and root $\mathrm{FW}$ and DW, SC, TSS, fruit average weight, total yield, lycopene, vitamin $C$, total chlorophyll, proline content, MDA, POX and CAT antioxidant enzymes, leaf mineral content.

When strawberry plants were exposed to $\mathrm{NaCl}$ stress, their crown FW and DW were reduced 53\% and $40 \%$, respectively when compared to those of controls. However, application of $\mathrm{NaCl}+\mathrm{HA}$ increased crown FW and DW contents by $90 \%$ and DW 95\%, respectively when compared to control plants (Figure $1 \mathrm{~A}$ and $\mathrm{B}$ ). HA application did not contribute to increases in FW and DW of strawberry plants grown in normal conditions. Similarly, root FW and DW of strawberry plants increased upon application of $\mathrm{HA}$ to $\mathrm{NaCl}$-treated plants, but the increase of root FW and DW were not as significant as those of increases in crown FW and DW of strawberry plants followed by application of HA (Table 1).

When SC was elucidated, $\mathrm{NaCl}$ application reduced SC by $42 \%$ however, $\mathrm{HA}$ application under $\mathrm{NaCl}$ stress led to reduction of SC by only $8 \%$. The application of $\mathrm{HA}$ to those $\mathrm{NaCl}$-treated plants significantly improved the stomatal conductance in those plants (Table 1).

Table 1. Strawberry same physiological parameters of strawberry plants HA application and NaCl-treated.

\begin{tabular}{|c|c|c|c|c|c|}
\hline Applications & $\begin{array}{l}\text { Crown FW } \\
\left(\text { g plant }^{-1}\right)\end{array}$ & $\begin{array}{l}\text { Crown DW } \\
\left.\text { (g plant }^{-1}\right)\end{array}$ & $\begin{array}{l}\text { Root FW } \\
\left.\text { (g plant }^{-1}\right)\end{array}$ & $\begin{array}{l}\text { Root DW } \\
\left(\text { g plant }^{-1}\right)\end{array}$ & $\begin{array}{c}S C \\
\left(m m o l ~ m^{-2} s^{-1}\right)\end{array}$ \\
\hline Control & $84.18 \pm 3.84^{a}$ & $9.75 \pm 0.26^{a}$ & $43.06 \pm 1.97^{\mathrm{a}}$ & $6.21 \pm 0.21^{\mathrm{a}}$ & $234.01 \pm 10.28^{a}$ \\
\hline $\mathrm{NaCl}$ & $39.90 \pm 3.32^{\mathrm{b}}$ & $5.90 \pm 0.20^{b}$ & $20.07 \pm 1.45^{c}$ & $2.28 \pm 0.14^{c}$ & $136.40 \pm 12.39^{\circ}$ \\
\hline$H A$ & $87.33 \pm 3.10^{\mathrm{a}}$ & $10.91 \pm 0.42^{\mathrm{a}}$ & $44.86 \pm 4.19^{a}$ & $6.92 \pm 0.39^{\mathrm{a}}$ & $246.08 \pm 12.81^{a}$ \\
\hline $\mathrm{NaCl}+\mathrm{HA}$ & $75.38 \pm 5.63^{\mathrm{a}}$ & $9.24 \pm 0.92^{\mathrm{a}}$ & $32.69 \pm 2.58^{b}$ & $4.24 \pm 0.22^{b}$ & $213.78 \pm 10.48^{b}$ \\
\hline
\end{tabular}

Significance level at $\mathrm{P} \leq 0.05$ was assessed for the $\mathrm{HA}$ and $\mathrm{NaCl}$ applications via Duncan's Multiple Range Test. Different letters in each column show significant statistical differences.

It was reported that HA promoted soil water holding capacity and reduced irrigation needs for plants (Orzolek, 1993; Hynes and Naidu, 1998). According to some reports, HA regulated hormone level, improved plant growth and enhanced stress tolerance (Piccolo et al., 1992; Moraditochaee. 2012). HA may induce shoot and root growth and improve defence to abiotic stress in plants but the physiological mechanism has not been well determined (Delfine et al., 2005). Masciandaro et al. (2002), Pilanali and Kaplan (2003) stated that HA application mitigated the salinity effect in strawberry, maize and pepper seedlings in saline conditions. 


\section{Fruit characteristics}

When strawberry plants were exposed to $\mathrm{NaCl}$ stress, their crown FW and DW were reduced 53\% and $40 \%$, respectively when compared to those of controls. However, application of $\mathrm{NaCl}+\mathrm{HA}$ increased crown FW and DW contents by $90 \%$ and DW 95\%, respectively when compared to control plants (Figure $1 \mathrm{~A}$ and $\mathrm{B}$ ).

Average fruit and total fruit weights were significantly dropped $39 \%$ and $65 \%$, respectively at $\mathrm{NaCl}$-treated strawberry plants. However, $\mathrm{HA}$ application under $\mathrm{NaCl}$ stress led to reduction of average fruit and total fruit weights by only $9 \%$ and $4 \%$, respectively when compared to controls (Figure 2A and 2B). It was observed that $\mathrm{NaCl}$ stress significantly decreased lycopene and vitamin $\mathrm{C}$ contents of the fruits. The application of
HA improved the quality of fruits that had been exposed to $\mathrm{NaCl}$. Although lycopene and vitamin $C$ contents of the fruits decreased under $\mathrm{NaCl}$ stress, this was not that significant as compared to those of other parameters taken in the vegetative stages. However, the application of HA still contributed to increasing of lycopene and vitamin $\mathrm{C}$ contents of strawberry fruits (Figure $2 \mathrm{C}$ and 2D).

TSS contents did not differ amog the treatments. Although $\mathrm{NaCl}$ application reduced the TSS of strawberry plants, the reduction of TSS was not that significant. Application of HA to $\mathrm{NaCl}$-treated plants increased the contents of TSS up to some degree, however, this was not statistically significant either (Figure 2E).
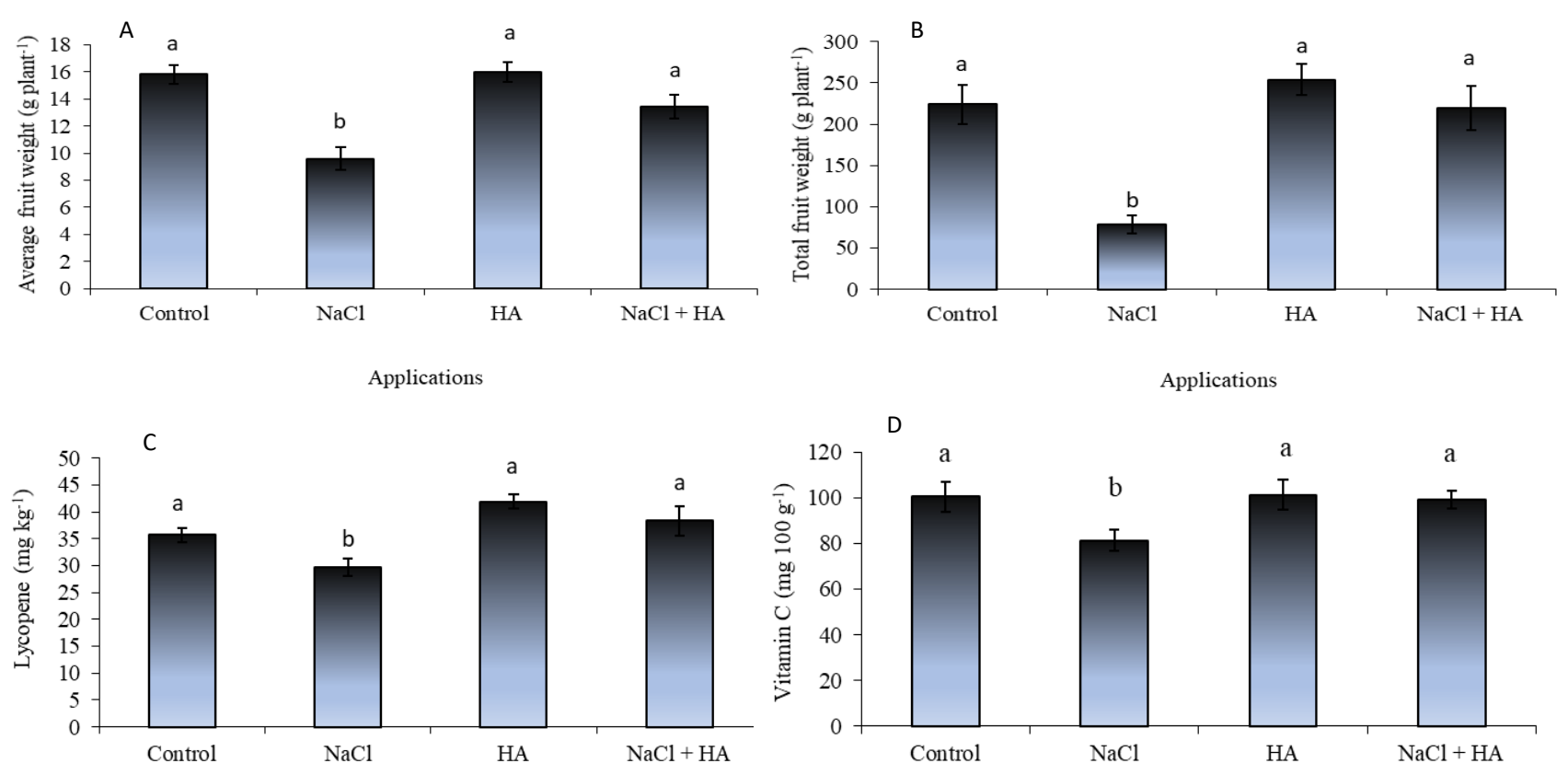

Applications

Applications

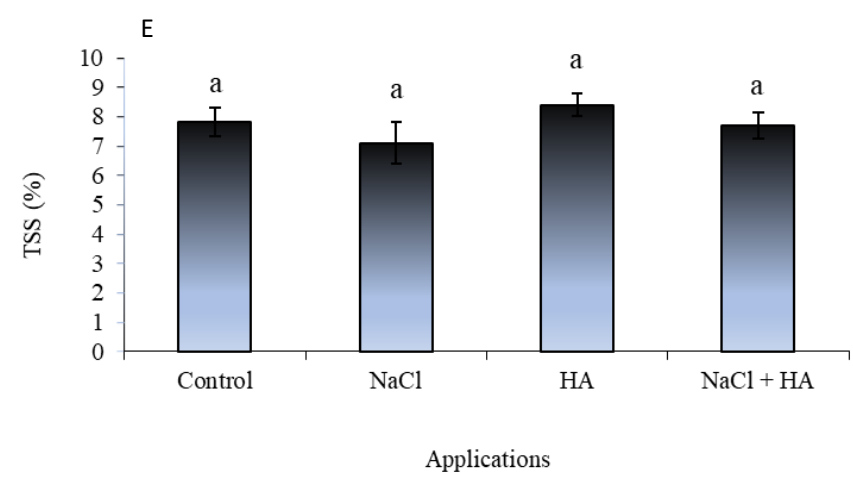

Figure 2. Effect of HA application on average fruit weight, yield lycopene, vitamin C and TSS of NaCl-treated strawberry (Rubygem) plants. Bars indicate the means of the five replicates \pm standard error. 
Decrease in strawberry yield under salinity stress could be attributed to reduction in photosynthesis and eventually reduction in the flower fruit formation (Saied et al., 2005). Salt stress can decrease fruit quality such as the vitamin $\mathrm{C}$ and lycopene content of strawberry (Jamalian et al. 2008; Karakas et al., 2021) Our results are in line with the results of previous studies.

\section{Biochemical characteristics}

Total chlorophyll contents of strawberry plants significantly decreased upon exposure to $\mathrm{NaCl}$ stress. Although the application of HA increased the total chlorophyll contents of plants, that was not satisfactory to increase the chlorophyll contents (Table 2). On the other hand, HA application on $\mathrm{NaCl}$-treated strawberry plants contributed to increase of chlorophyll contents. The increase of chlorophyll was found statistically satisfactory in which the chlorophyll contents of $\mathrm{NaCl}$-treated plants increased from 1.24 to 1.97 in $\mathrm{NaCl}+\mathrm{HA}$-treated plants. One of the main mechanisims behind this could be attributed to increased acctivity of photossnthetic compounds. For example, Fan et al. (2014) stated that chlorophyll contents of Chrysanthemum plants were significantly increased upon HA application. It is suggested that the increase of chlorophyll contents were due to increased metabolic activities led by HA application. We state the same pattern in strawberry plants.

Leaf proline content significantly increased as a response to $\mathrm{NaCl}$-treatment. The application of HA significantly decreased the proline contents (Table 2).

Again, leaf MDA contents in strawberry increased with the $\mathrm{NaCl}$-treatment as a response to stress. HA application had also a remarkable effect to decrease MDA level in $\mathrm{NaCl}$-treated strawberry plants. (Table 2).

CAT and POX antioxidant enzyme activities showed a parallel pattern as those of previous parameters. HA application significantly decreased antioxidant enzyme activities $\mathrm{NaCl}$ treated (Table 2).

Table 2. Strawberry biochemical parameters of strawberry plants HA application and NaCl-treated.

\begin{tabular}{cccccc}
\hline Applications & $\begin{array}{c}\text { Total chlorophyll } \\
\left(\mathrm{mg} \mathrm{g}^{-1}\right)\end{array}$ & $\begin{array}{c}\text { Proline } \\
\left(\mu \mathrm{mol} \mathrm{g}^{-1}\right)\end{array}$ & $\begin{array}{c}\text { MDA } \\
\left(\mathrm{nmol} \mathrm{g}^{-1}\right)\end{array}$ & $\begin{array}{c}\text { CAT } \\
\text { (unit mg } \mathrm{FW}^{-1} \mathrm{FW}\end{array}$ & $\begin{array}{c}\text { POX } \\
\left(\text { unit mg } \mathrm{FW}^{-1} \mathrm{FW}\right.\end{array}$ \\
\hline $\mathrm{Control}$ & $2.19 \pm 0.10 \mathrm{a}$ & $2.90 \pm 0.42 \mathrm{~b}$ & $1.87 \pm 0.13 \mathrm{~b}$ & $1.85 \pm 0.20 \mathrm{~b}$ & $4.68 \pm 0.40$ \\
$\mathrm{NaCl}$ & $1.24 \pm 0.17 \mathrm{~b}$ & $10.56 \pm 1.30 \mathrm{a}$ & $5.31 \pm 0.36 \mathrm{a}$ & $5.49 \pm 0.40 \mathrm{a}$ & $13.69 \pm 1.07$ \\
$\mathrm{HA}$ & $2.34 \pm 0.14 \mathrm{a}$ & $2.70 \pm 0.24 \mathrm{~b}$ & $1.99 \pm 0.21 \mathrm{~b}$ & $1.36 \pm 0.18 \mathrm{~b}$ & $4.51 \pm 0.50$ \\
$\mathrm{NaCl}+\mathrm{HA}$ & $1.97 \pm 0.22 \mathrm{a}$ & $3.68 \pm 0.82 \mathrm{~b}$ & $2.57 \pm 0.35 \mathrm{~b}$ & $2.22 \pm 0.24 \mathrm{~b}$ & $5.20 \pm 0.66$ \\
\hline
\end{tabular}

Significance level at $\mathrm{P} \leq 0.05$ was assessed for the $\mathrm{HA}$ and $\mathrm{NaCl}$ applications via Duncan's Multiple Range Test. Different letters in each column show significant statistical differences.

Under saline conditions, compatible solutes like proline and soluble carbohydrates are expected to accumulate (Yaghobi et al., 2016). Increases in proline and soluble carbohydrates can be used as indicators of salinity tolerance ability (Munns and Tester, 2008). It was reported that proline increases positively correlated with $\mathrm{HA}$ application under $\mathrm{NaCl}$ stress (Jarosova et al., 2016). On the other hand, Jarosova (2016) reported the opposite finding that the amount of proline diminished in plants treated with HA under saline stress. It was suggested that the decrease in proline and soluble carbohydrate content in plants treated with HA may be related to the alleviation mechanism of harmful effects of salinity. In our findings, HA application did not increase proline contents under normal conditions, on the contrary, it decreased proline contents under $\mathrm{NaCl}$ stress conditions. $\mathrm{NaCl}$ stress was observed to increase proline contents. It was remarkable to see that $\mathrm{HA}$ application proline contents in $\mathrm{NaCl}$-treated plants. Our findings were similar to findings observed by Jarosova (2016). We assumed that mostly proline accumulation in salt-sensitive plants caused from the degradation of protein rather than synthesis in cells. It is 
possible that HA application decreased the damaged proteins and prevented protein oxidation. This was reflected as decreases in proline contents in $\mathrm{NaCl}$ stressed plants. These observations were also positively tested when we recorded other parameters such as MDA accumulations. MDA is an important marker to determine if lipid peroxidation or damage to the plasmalemma and membranes of intracellular organelles has occurred as a result of environmental stresses (Halpern et al., 2015). In saline conditions, an increase in the number of free radicals causes membrane fats to decompose and MDA to be production (Bernstein et al., 2010). In this study, HA remarkably diminished MDA content under salinity stress. Since HA regulated the antioxidant enzymes in the host cell and limited the levels of ROS and lipid peroxidation, the application of HA could be benefical for the plants under stress (Lotfi et al., 2015; Saidimoradi et al., 2019). The similar case was proved in our study. The stress marker via MDA measuremet showed that was significantly reduced. This clearly showed that HA was able to reduce the $\mathrm{NaCl}$ stress and the metabolites produced for the ease of $\mathrm{NaCl}$ stress was spent to increase quality parameters as shown above.

\section{Some leaf mineral contents}

The effect of HA and salt stress on leaf mineral contents such as $\mathrm{N}, \mathrm{P}, \mathrm{K}^{+}, \mathrm{Ca}^{2+}$ and $\mathrm{Mg}^{2+}$ ions decreased with the increases in salinity levels in strawberry plants. The lowest $\mathrm{K}^{+}$and $\mathrm{Ca}^{2+}$ ions were determined following $\mathrm{NaCl}$ application. $\mathrm{HA}$ application enhanced $\mathrm{N}$ and $\mathrm{P}$ ions, but $\mathrm{Mg}^{2+}$ has not been changed significantly in strawberry plants following $\mathrm{NaCl}$ treatments. Under saline conditions, increases of $\mathrm{Na}^{+}$and $\mathrm{Cl}^{-}$ions were evident in strawberry plants grown at increasing $\mathrm{NaCl}$ salinity, however, employment of HA significantly decreased the $\mathrm{Na}^{+}$and $\mathrm{Cl}^{-}$ions, Table 3.

Table 3. Strawberry leaf mineral contents.

\begin{tabular}{lccccccc}
\hline Applications & $\begin{array}{c}N \\
(\%)\end{array}$ & $\begin{array}{c}P \\
(\%)\end{array}$ & $\begin{array}{c}K^{+} \\
(\%)\end{array}$ & $\begin{array}{c}\mathrm{Na}^{-} \\
(\%)\end{array}$ & $\begin{array}{c}\mathrm{Ca}^{++} \\
(\%)\end{array}$ & $\begin{array}{c}\mathrm{Mg}^{++} \\
(\%)\end{array}$ & $\begin{array}{c}\mathrm{Cl}^{-} \\
(\%)\end{array}$ \\
\hline Control & $2.21 \pm 0.28^{\mathrm{a}}$ & $0.88 \pm 0.11^{\mathrm{a}}$ & $2.77 \pm 0.10^{\mathrm{a}}$ & $0.21 \pm 0.02^{\mathrm{c}}$ & $1.92 \pm 0.06^{\mathrm{a}}$ & $0.31 \pm 0.02^{\mathrm{a}}$ & $0.30 \pm 0.03^{\mathrm{c}}$ \\
$\mathrm{NaCl}$ & $1.81 \pm 0.18^{\mathrm{b}}$ & $0.62 \pm 0.07^{\mathrm{b}}$ & $1.76 \pm 0.20^{\mathrm{b}}$ & $1.13 \pm 0.08^{\mathrm{a}}$ & $1.68 \pm 0.03^{\mathrm{b}}$ & $0.29 \pm 0.01^{\mathrm{a}}$ & $1.40 \pm 0.11^{\mathrm{a}}$ \\
$\mathrm{HA}$ & $2.63 \pm 0.26^{\mathrm{a}}$ & $1.03 \pm 0.14^{\mathrm{a}}$ & $2.60 \pm 0.07^{\mathrm{a}}$ & $0.19 \pm 0.01^{\mathrm{c}}$ & $2.11 \pm 0.12^{\mathrm{a}}$ & $0.34 \pm 0.02^{\mathrm{a}}$ & $0.26 \pm 0.04^{\mathrm{c}}$ \\
$\mathrm{NaCl}+\mathrm{HA}$ & $2.30 \pm 0.27^{\mathrm{a}}$ & $0.77 \pm 0.05^{\mathrm{a}}$ & $2.54 \pm 0.11^{\mathrm{a}}$ & $0.58 \pm 0.06^{\mathrm{b}}$ & $1.91 \pm 0.11^{\mathrm{a}}$ & $0.33 \pm 0.03^{\mathrm{a}}$ & $0.47 \pm 0.06^{\mathrm{b}}$ \\
\hline
\end{tabular}

Significance level at $\mathrm{P} \leq 0.05$ was assessed for the $\mathrm{HA}$ and $\mathrm{NaCl}$ applications via Duncan's Multiple Range Test. Different letters in each column show significant statistical differences.

Above parameters and mineral nutrient absorption rates are combined to assess the function of $\mathrm{HA}$ in reducing the negative effects of salt on plants. The effects of HA on nutrient absorption in plants have been extensively researched in terms of growth conditions and plant varieties. For instance, HA prolonged the uptake of $\mathrm{P}, \mathrm{K}^{+}, \mathrm{Ca}^{2+}, \mathrm{Mg}^{2+}, \mathrm{Na}^{+}, \mathrm{Zn}^{2+}, \mathrm{Fe}^{3+}, \mathrm{Mn}^{2+}$ and $\mathrm{Cu}^{2+}$ in Solanum melongena $\mathrm{L}$. and tomato plants (Dursun et al.,1999); in maize such as N, $\mathrm{P}$, $\mathrm{K}^{+}, \mathrm{Ca}^{2+}, \mathrm{Zn}^{2+}, \mathrm{Fe}^{3+}, \mathrm{Mn}^{2+}$ and $\mathrm{Cu}^{2+}$ (Sharif et al., 2002; Eyheraguibel et al., 2008); N, $\mathrm{P}, \mathrm{K}^{+}$in tomato plants (Abdel-Mawgoud et al., 2007). Effects of HA on mineral uptake in saline-stressed strawberry plants were quite remarkable as shown in this study. $\mathrm{NaCl}$ stress significantly increased $\mathrm{Na}^{+}$and $\mathrm{Cl}^{-}$ion accumulation in leaves of strawberry plants while decreasing other beneficial minerals such as $\mathrm{N}, \mathrm{P}, \mathrm{K}^{+}, \mathrm{Mg}^{++}$, and $\mathrm{Ca}^{++}$. Application of $\mathrm{HA}$ not only regulated metabolic homeostasis but also improved beneficial mineral uptake while developing the uptake of toxic ions like $\mathrm{Na}^{+}$and $\mathrm{Cl}^{-}$ions. This is probably due to increased root system and photosynthetic capacity. Positive effects of HA applications were observed on strawberry plants grown in normal conditions. As expressed above, $\mathrm{HA}$ application improved the rooting system of those plants grown in normal conditions in which the uptake of mineral elements are increased significantly. Our study showed that saline stress reduced $\mathrm{K}^{+}$ion concentration while increasing $\mathrm{Na}^{+}$ 
concentration in leaf. It was reported that salinity increased $\mathrm{Na}^{+}$deposition ratio in root growing region and decreased the selectivity for $\mathrm{K}^{+}$ (Saidimoradi et al., 2019). However, HA application improved and regulated mineral homeostasis in strawberry plants. Similar results were reported by Keutgen and Pawelzik (2009) who determined an increase in $\mathrm{Na}^{+}$ion content in the leaf and root of strawberry plants when they were exposed to saline stress.

\section{Conclusion}

One of the most critical and destructive abiotic stresses affecting agriculture worldwide is salinity stress. Since strawberry is a salt-sensitive plant, it is easily affected by a mild or moderate level of salinity. A very low level of $\mathrm{NaCl}$ could significantly reduce the crop yield and quality of fruits.

In this study, strawberry was grown under differing applications (control, $50 \mathrm{mmol} \mathrm{L}^{-1} \mathrm{NaCl}$, $50 \mathrm{mg} \mathrm{L}^{-1} \mathrm{HA}, 50 \mathrm{mmol} \mathrm{L}^{-1} \mathrm{NaCl}+50 \mathrm{mg} \mathrm{L}^{-1} \mathrm{HA}$ ). Strawberry seedlings in $\mathrm{NaCl}$ salinity were negatively affected in terms of physiological and biochemical parameters. Defending plants synthesized various stress metabolites such as proline, MDA, POX and CAT antioxidant enzymes to ease the negative effects of $\mathrm{NaCl}$ toxicity. However, increases of these metabolites were negatively correlated with the quality-related metabolites such as vitamin $\mathrm{C}$ and lycopene contents. HA applications reduced the concentrations of stress metabolites and antioxidant enzyme levels and contributed to increases of vitamin $\mathrm{C}$ and lycopene contents indirectly in strawberry plants. This study showed that HA application might be an effective approach to increase the yield production and quality of strawberry fruits. We suggest that use of HA in strawberry plants is a practical approach where salinity is prevalent.

Acknowledgments: The authors express their sincere grattidues to Prof. Ibrahim Bolat for his help during cultivation of strawberry.
Author Contributions: Conceptualization, S.K., M.D.; methodology, S.K., and M.D.; validation, S.K., and M.D.; formal analysis, S.K. and M.D; investigation, S.K., M.D; resources, S.K., and M.D; writing-original draft preparation, S.K.; writingreview and editing, M.D. All authors have read and agreed to the published version of the manuscript".

Conflicts of Interest: The authors declare no conflict of interest.

\section{References}

Abdel-Mawgoud, A. M. R., El-Greadly, N. H. M., Helmy, Y. I., \& Singer, S. (2007). Responses of tomato Plants to different rates of humic-based fertilizer and NPK fertilization. Journal of Applied Sciences Research, 3, 169-174.

Ali, A. Y. A., Ibrahim, M. E. H., Zhou, G., Nimir, N. E. A., Jiao, X., Zhu, G., Elsiddig A. M. I., Zhi, W., Chen, X., \& Lu, H. (2019). Ameliorative effects of jasmonic acid and humic acid on antioxidant enzymes and salt tolerance of forage sorghum under salinity conditions. Agronomy Journal, 111(6), 3099-3108.

Arnon, D. L. A. (1949). Copper enzyme is isolated chloroplast polyphenol oxidase in Beta vulgaris. Plant Physiol, 24, 1-15.

Aydin, A., Kant, C., \& Turan, M. (2012). Humic acid application alleviate salinity stress of bean (Phaseolus vulgaris L.) plants decreasing membrane leakage. African Journal of Agricultural Research, 7, 1073-1086.

Barrett, D. M., \& Anthon, G. (2001). Lycopene content of calıfornia-grown tomato varieties. Acta Horticulturae, 542, 165-174.

Bates, L. S., Waldren R. P., \& Teare, I. D. (1973). Rapid determination of free proline for water-stress studies. Plant and Soil, 39, 205-207.

Bernstein, N., Shoresh, M., Xu, Y., \& Huang, B., (2010). Involvement of the plant antioxidative response in the differential growth sensitivity to salinity of leaves vs roots during cell development. Free Radical Biology Medicine, 49 (7), 1161-1171

Canellas, L. P., \& Olivares, F. L. (2014). Physiological responses to humic substances as plant growth promoter. Chemical and Biological Technologies. Agriculture, 1 (3), 1-11.

Canellas, L.P., Olivares, F.L., Aguiar, N.O., Jones, D.L., Nebbioso, A., Mazzei, P., \& Piccolo, A., (2015). Humic and fulvic acids as biostimulants in horticulture. Scientia Horticulturae, 196, 15-27.

Catania, P., Comparetti, A., De Pasquale, C., Morello, G., \& Vallone, M. (2020). Effects of the Extraction Technology on Pomegranate Juice Quality. Agronomy, 10, 10, 1483.

Chapman H. D. \& Pratt P. F. (1961). Methods of analysis for soils, plants, and waters. Division of agricultural 
sciences, University of California USA.

Cvikrova, M., Hrubcova, M., Vagner, M., Machackova, I., \& Eder, J. (1994). Phenolic acids and peroxidase activity in Alfalfa (Medicago sativa) embryogenic cultures after ethephon treatment. Plant Physiological, 91(2), 226-233.

Delfine, S., Tognetti, R., Desiderio, E., \& Alvino, A. (2005). Effect of foliar application of $\mathrm{N}$ and humic acids on growth and yield of durum wheat. Agronomy for Sustainable Development, 25, 183-191.

Dursun, A., Güvenç, İ., \& Turan, M. (1999). Macro and micro nutrient contents of tomato and eggplant seedlings and their effects on seedling growthin relation to humic acid application, Improved Crop Quality by Nutrient Management, Anaç, D.; Martin-Prevel, P.Editors.; Kluwer Academic Publishers, Dordrecht, Boston, London.

Eyheraguibel, B., Silvestre, J., \& Morard, P. (2008). Effects of humic substances derived from organic waste enhancement on the growth and mineral nutrition of maize, Bioresource Technology. 99: 4206-4212.

Fan, H. M., Wang, X. W., Sun, X., Li, Y. Y., Sun, X. Z., \& Zheng, C.S., (2014). Effects of humic acid derived from sediments on growth, photosynthesis and chloroplast ultrastructure in chrysanthemum, Scientia Horticulturae, 177, 118-123.

Folta, K.M., \& Davis, T.M. (2006). Strawberry genes and genomics. Critical Reviews in Plant Sciences, 25, 399415.

Garriga, M., Muñoz, C.A., Caligari, P.D., \& Retamales, J.B. (2015). Effect of salt stress on genotypes of commercial (Fragaria $\mathrm{x}$ ananassa) and Chilean strawberry (F. chiloensis). Scientia Horticulturae, 195, 37-47.

Geçer, M. K. (2020). ffects of Humic Acid Application on Fruit Yield and Quality in Some Strawberry Cultivars. International Journal of Agriculture and Wildlife Science, 6(1), $21-27$.

Halpern, M., Bar-Tal, A., Ofek, M., Minz, D., Muller, T., \& Yermiyahu, U., (2015). The use of biostimulants for enhancing nutrient uptake. Advances in Agronomy, 130, 141-174.

Hynes, R.J., \& Naidu, R. (1998). Influence of lime, fertilizer and manure application on soil organic matter content and soil physical conditions. A review of Nutrient Cyclic and Agroecosystem, 51:123-137.

Jamalian, S., Gholami, M., \& Esna-Ashari, M. (2013). Abscisic acid-mediated leaf phenolic compounds, plant growth and yield is strawberry under different salt stress regimes. Theoretical and Experimental Plant Physiology, 25, 291-299.

Jamalian, S., Tehranifar, A., Tafazoli, E., Eshghi, S., \& Davarynejad, G.H. (2008). Paclobutrazol application ameliorates the negative effect of salt stress on reproductive growth, yield, and fruit quality of strawberry plants. Horticulture, Environment and Biotechnology, 49, 1-6.

Jarosova, M., Klejdus, B., Kovacik, J., Babula, P., \& Hedbavny, J., (2016). Humic acid protects barley against salinity. Acta Physiologiae Plantarum, 38 (161), 1-9.

Karakas, S. (2013). Development of tomato growing in soil differing in salt levels and effects of companion plants on same physiological parameters and soil remediation. PhD University of Harran, Sanlıurfa, Turkey.

Karakas, S., Bolat I., \& Dikilitas M. (2021). The Use of Halophytic Companion Plant (Portulaca oleracea L.) on Some Growth, Fruit, and Biochemical Parameters of Strawberry Plants under Salt Stress. Horticulturae, 7, 63.

Karakas, S., Cullu M.A., Kaya, C., \& Dikilitas, M. (2016). Halophytic companion plants improve growth and physiological parameters of tomato plants grown under salinity. Pakistan Journal of Botany, 48, 21-28.

Karlidag, H., Yildirim, E., \& Turan, M. (2011). Role of 24epibrassinolide in mitigating the adverse effects of salt stress on stomatal conductance, membrane permeability, and leaf water content, ionic composition in salt stressed strawberry (Fragaria $x$ ananassa). Scientia horticulturae, 130 (1), 133-140.

Keutgen, A. J., \& Pawelzik, E., (2009). Impacts of $\mathrm{NaCl}$ stress on plant growth and mineral nutrient assimilation in two cultivars of strawberry. Environmental and Experimentai Botany, 65 (2-3), 170-176.

Lotfi, R., Pessarakli, M., Gharavi-Kouchebagh, P., \& Khoshvaghti, H., (2015). Physiological responses of Brassica napus to fulvic acid under water stress: Chlorophyll a fluorescence and antioxidant enzyme activity. Crop Journal, 3 (5), 434-439.

Masciandaro, G., Ceccanti, B., Ronchi, V., Benedicto, S., \& Howard, L. (2002). Humic substances to reduce salt effect on plant germination and growth. Communications in Soil Science and Plant Analysis, 33, 365-378.

Milosevic, N., \& Slusarenko, A. J. (1996). Active Oxygen Metabolism and Lignifications in The Hypersensitive Response in Bean. Physiological and Molecular Plant Pathology, 49, 143-158.

Moraditochaee M. (2012). Effects of humic acid foliar spraying and nitrogen fertilizer management on yield of peanut (Arachis hypogaea L.) in Iran. ARPN Journal of Agricultural and Biological Science, 7, 289-293.

Munns, R., \& Tester, M. (2008). Mechanisms of salinity tolerance. Annual Review of Plant Biology, 59, 651681.

Orzolek, M. (1993). Use of hydrophilic polymers in horticulture. Hort. Tecnol., 3: 41-44.

Oz, A. T. (2002). Effects of two differrent temperatures on Iascorbic acid content (Vitamın C), lenght of storage time and fruit quality. Bahce, 31(1-2), 51-57.

Piccolo, A., Nardi, S., \& Concheri, G. (1992). Structural characteristics of humic substance as related to nitrate uptake and growth regulation in plant systems. Soil Biology Biochemistry, 24, 373-380.

Pilanalı, N., \& Kaplan, M. (2003). Investigation of Effects on Nutrient Uptake of Humic Acid Applications of Different Forms to Strawberry Plant. Journal of Plant Nutrition. 26, 4, 838843.

Saidimoradia, D., Ghaderia, N., \& Javadia, T. (2019). Salinity stress mitigation by humic acid application in strawberry (Fragaria $\mathrm{x}$ ananassa Duch.). Scientia Horticulturae 256, 108594.

Saied, A.S., Keutgen, A.J. \& Noga, G. (2005). The influence of $\mathrm{NaCl}$ salinity on growth, yield and fruit quality of strawberry cvs. 'Elsanta'and 'Korona'. Scientia 
Horticulturae, 103, 289-303.

Sairam, R.K., \& Sexena, D. (2000). Oxidative stress and antioxidants in wheat genotypes: possible mechanism of water stress tolerance. Journal of Agronomy and Crop Science, 184, 55-61.

Sharif, M., Khattak, R. A., \& Sarir, M.S. (2002). Effect of different levels of lignitic coal derived humic acid on growth of maize plants, Soil Science and Plant Analysis. 33, 3567- 3580.

Shulaev, V.; Korban, S. S.; Sosinski, B.; Abbott, A.G.; Aldwinckle, H.S.; Folta, K.M.; lezzoni, A.; Main, D.; Arús, P.; Dandekar, A.M.; Lewers, K.; Brown, S. K.; Davis, T.M.; Gardiner, S.E., Potter, D., \& Veilleux, R.E. (2008). Multiple models for rosaceae genomics. Plant Physiology, 147, 985-1003.
Trevisan, S., Pizzeghello, D., Ruperti, B., Francioso, O., Sassi, A., Palme, K., Quaggiotti, S. \& Nardi, S. (2009). Humic substances induce lateral root formation and expression of the early auxin-responsive IAA19 gene and DR5 synthetic element in Arabidopsis. Plant Biology, 12, 604-614.

Wani, S.H., \& Gosal, S.S., (2011). Introduction of Osglyll gene into Oryza sativa for increasing salinity tolerance. Biologia Plantarum, 55 (3), 536-540.

Yaghubi, K., Ghaderi, N., Vafaee, Y., \& Javadi, T. (2016). Potassium silicate alleviates deleterious effects of salinity on two strawberry cultivars grown under soilless pot culture. Scientia Horticulturae, 213, 8795. 